\title{
Evaluation of Bread From Frozen Dough
}

\author{
Rosario G. Catapang, Segundila S. Malilay \\ rosecatapangphd@gmail.com
}

Faculty, Laguna State Polytechnic University, Santa, Cruz, Laguna 4009, Philippines

Faculty, Laguna State Polytechnic University, Santa Cruz, Laguna 4009, Philippines

\begin{abstract}
This study entitled "EVALUATION OF SOFT ROLL BREAD FROM FROZEN DOUGH” aimed to determine if frozen dough could be utilized in the preparation of bread. It also attempted to find out the effect of length of freezing to the baking performance of the bread, the level of acceptability of the bread to the different consumers based on the sensory qualities such as aroma, texture, taste, appearance and general acceptability. Added to that significant difference on the preparation of bread from frozen dough and shelf-life of the product at room temperature are to be tested.
\end{abstract}

Experimental method was employed to answer the problems presented and to develop and revise the products. Adults, bakers and students use sensory evaluation sheet to gather the data on the acceptability of bread from frozen dough.

In summary, computed mean and standard deviation showed that the bread from frozen dough using one (1) week old dough was highly acceptable compared to one (1) month old dough. It also revealed that group of adults liked very much the product while the bakers, students, and instructors liked moderately. With respect to the sensory qualities, taste got the highest rate followed by texture and aroma. Appearance got the lowest rate. It was proven that the product could be stored for three (3) days at room temperature after baking since it is highly acceptable.

It revealed that taste gave the significant difference while aroma, texture and appearance have no significant difference in the preparation of bread from frozen dough. 
It is therefore concluded that the bread using one (1) week old was highly acceptable to the group of respondents.

Keywords: acceptability; evaluation; frozen dough; sensory qualities; soft-roll bread

\section{Background and Rationale}

The responsibilities of the faculty in our University are not only bounded to teaching, research and extension service must also be performed. Extension service is conducted in response to the needs of the community. Every semester the bread and pastry production team was invited to extend their trainings in the nearby towns in Laguna. The recipients of the said training will not only acquaint them the basic knowledge about baking but at the same time will give them a chance to start a small business enterprise by selling the baked products learned from the trainings and other young trainees, will be qualified to take the examination given by the TESDA, the National Competency Level II Assessment on Pastry and Bread Production, that will equipped them with the needed competencies for international job opportunities.

Proportions of types of flour and other ingredients vary widely, as do modes of preparation. As a result, types, shapes, sizes, and textures of breads differ. Bread are leavened by yeast and fermented for several hours to make it soft and tender.Non-cereal ingredients such as fruits, nuts and fats may be included. Commercial bread commonly contains additives to improve flavor, texture, color, shelf life, and ease of manufacturing. Edwards (2007).

One such product taught during the training is bread in the form of soft roll. It is a staple food prepared from dough of flour and other ingredients that contains lots of nutrients that promote good health.

Common problems in the preparation of bread are the use of proper ingredients, the right formula pertaining to accuracy of the recipe, perishability, and the production timing. Time was always the problem encountered during extension service on bread and pastry production. Preparation and baking of bread requires high degree of skills and ample time. Two (2) hours sometimes is not enough for the 
fermentation and rising period of dough to assure good quality. It is the reason why length of preparation becomes a problem in baking soft roll bread.

Baking is an enjoyable, interesting and challenging activity. Anyone who has knowledge and skills about it is encouraged to practice by preparing bread even for family consumption only. With these experiment there is an assurance that bread to be eaten is free from preservatives that can harm one's health, nutritious, and at the same it is prepared under sanitary condition. Individual who bake bread also receive a great deal of satisfaction from its preparation.

In this study, ways on how to facilitate the method of bread preparation by lessening the time consumed in baking will be introduced by the use of freezing. The dough will be frozen for several days and it will be tried if it possible to prepare big quantities of dough to be used for some other day or even for month long. It will be experimented also if freezing a bulk of dough and thawing a small amount for baking is advisable in an appointment period. When proven effective, this will be introduce to the College extension Program on Bread and Pastry Production and at the same time to the laboratory activities of the students of the College having baking competencies in their subject.

\section{Objectives}

The purpose of this experimental study is to determine if frozen dough can be in the preparation of soft roll bread. Specifically, it aim to find out the following:

1. Determine the baking performance of soft roll bread from frozen dough based on the following preparation:
a. One (1) week in freezing; and
b. One month in freezing.

2. Test the level of acceptability of soft roll bread from frozen dough in terms of the sensory qualities such as:

\section{1. appearance;}

2.2. aroma; 
2.3. taste; and

2.4. texture.

3. Determine the significant difference on the level of acceptability of the soft roll bread from frozen dough based on sensory qualities as rated by:

3.1. teenagers;

3.2. housewives; and

3.3. bakers.

\section{Review of Related Literature}

Bread comes in thousands of forms. What do they have in common? On the most basic level, they all involve cooking a mixture of milled grains and water. Raised breads, on the other hand, involve the complex interactions between flour and the leaveners that give them their porous, tender quality. Cauvain, (2015).

Gilsen (2004) discussed the twelve steps of bread making as follows: Scaling is the exact measurement of all ingredients (professional bakers and dedicated amateurs measure by weight) and the French term, mise-en-place, applies to having all the ingredients scaled or prepped and ready before starting production.

Mixing and kneading involve the incorporation by hand or by machine of the ingredients in proper sequence to form the bread dough, which is then further kneaded. Kneading or working the dough by hand or by machine further disperses the ingredients and develops the gluten in the dough.

Fermentation, also referred to as the first rise, is the process whereby the gluten (protein) in the dough is allowed to relax while the yeast grows and reproduces. The yeast digests the sugars in the flour and produces alcohol and carbon dioxide $\left(\mathrm{CO}_{2}\right)$. The carbon dioxide gets trapped in the pockets that result from the kneading process and causes the bread to expand or rise and develop flavor. At this point the dough can be left at room temperature if it is to be baked that day, or it can be retarded; that is, the fermentation period can be extended in a cool environment, usually a specialized refrigerator. Dough that have been retarded for twelve to twenty-four hours generally have more complex flavors and are easier to 
fit into the baker's production schedule. There is also a noticeable buildup of natural acidity, which helps extend shelf life.

Punching down or deflating the dough, also called turning, refers to the general deflating of the dough mass by either gently pushing down or folding the dough, not hitting it as implied. The purpose is twofold, to increase the strength and tolerance of the gluten and to de-gas the dough prior to scaling. After punching, the dough is allowed to rest before moving on to the next step.

Scaling is cutting and weighing individual pieces of dough, which will become the actual loaves of bread.

Rounding occurs once the dough has been scaled. Each piece is gently shaped into a round ball before moving on to the next step. This rounding allows uniformity in subsequent steps.

Benching is allowing the dough pieces to rest, usually for fifteen to twenty minutes. The time varies with each type of bread and with the amount of leavening used. Clean, dry towels placed over the dough during this period prevent a dry crust from forming on the dough.

Make-up is forming the individual pieces of dough into their final shapes, free-form loaf, pan loaf, dinner rolls, and so forth.

Proofing, also referred to as the final rise, allows the dough to rise one last time before baking. The yeast is still alive and continues to leaven the dough. Proofing generally takes place in a warm, draftfree environment either at room temperature or in a proof box, where temperature and humidity are controlled. At this point shaped loaves can be retarded for twelve to twenty-four hours and baked at a later time.

According to Pena,( 2016) Baking is the actual cooking of the bread. When the dough is put in the hot oven, it undergoes oven spring, one last push of the yeast to make the dough rise. The actual temperature and time depend on the oven type (deck, rotary, convection, rack, and so forth) and the use of steam, although yeast breads are generally baked at a high temperature. Technically speaking, this is when the starches gelatinize and sugars caramelize, giving the loaf its final appearance. 
Cooling begins when the finished bread is removed from the oven. The bread cools completely before it is packaged or sliced. Cooling racks are usually nothing more than wire shelves that allow air circulation on all four sides of the bread. Even breads baked in or on pans are quickly removed to a cooling rack so the bread bottoms do not become soggy from continued steaming.

Storing prevents the staling or starch that begins as soon as the bread is removed from the oven. To preserve their thin, crisp crusts, some breads are best not packaged (lean breads in particular), but modern baking and distribution practices require many bakers to do so. Once a loaf has been put into a bag, the staling process is somewhat slowed down and the crust becomes soft. Wrapping and freezing help maintain quality for a longer period of time. Refrigeration, on the other hand, speeds up staling.

De Leon and De Guzman (2006) states that the preservation of food by freezing is not only the fastest method of food preservation, but freezing also produce the least changes in the nutritive, chemical, and physical characteristics of food. Although, freezing by the cold temperature decreases the microorganisms that are present in food, microbial growth can take place when food is thawed and some foods show a definite change in texture.

Frozen food needs a temperature of 0 degree Fahrenheit or less to maintain food quality. To preserve the quality of frozen food and to prevent its deterioration, it is important to use the proper wrapping or containers for frozen foods such as freezer foil, plastic wrap, and paper that is wax or plastic coated on one side. Waxed paper, bread paper, paper bags or regular cellophane should not be use, as these wrappings are not moisture or vapor-proof materials.

It is better from the safety perspective to reheat frozen cooked dishes without thawing. If the food is to be completely thawed before reheating, the food should be left in the refrigerator and heated immediately after thawing is completed. Partially thawed frozen food s can be refrozen only if many ice crystals still remain in the food. Foods should not be eaten of refrozen after they have reached a temperature of 50 degrees Fahrenheit. Bacterial growth can begin after two hours.

Palatability is a food's ability to evoke a sense of pleasure and enjoyment when eaten, which is also referred to as the hedonic reward. A food's perceived level of palatability is largely dependent on the 
individual's preferences. Certain factors such as taste, texture, smell, and appearance also strongly influence whether a food is considered to be palatable. People tend to eat larger amounts of foods that are palatable before deciding they are full than of less enjoyable dishes. The most palatable foods are not always highly nutritious, which can present a challenge for those trying to eat healthfully.

A food with a high level of palatability provides a person with an intense sense of pleasurable satisfaction. The sensations these foods create while being eaten activate the pleasure center in the brain. This often leaves a person wanting more because the experience was so enjoyable, and some may develop cravings for particular dishes. To a certain extent, how palatable an individual perceives a certain food is depends on personal preference. For example, one person may find sweet, creamy dishes to be the most palatable, while another may prefer crunchy, salty foods. (www.wisegeekhealth.com/what-ispalatability.htm)

Sensory evaluation is a scientific discipline that analyses and measures human responses to the composition of food and drink, e.g. appearance, touch, odor, texture, temperature and taste..

The precise way in which sensory evaluation is conducted, along with the different tests and sensory language used, needs to be taught. This will help students to understand the process and develop their sensory vocabulary. It also means that students will record and generate evaluative feedback to support their work. (www.foodafactoflife.org.uk/Sheet.aspx?siteId=19\&sectionId=83\&contentId=308)

Our 10,000 or so taste buds play the most vital role in food selection. Beyond taste, sensory properties such as smell, sound, appearance and texture influence what we select to eat. Food must taste delicious, certainly, but mouth feel, texture, looks and smell are also important to the overall eating experience. Foods must smell fresh or ripe, and have what we recognize as the proper color, size, shape, consistency and opacity. Thumping a melon, for example, tells us a lot about its texture and ripeness, as does checking other foods for flakiness, moistness, dryness, oiliness and so on.

Sound is important, as consumers know foods must maintain a certain level of crunch, bubble, sizzle, pop, snap and crackle, without negatively affecting shelf life or nutritional profile. Food that's 
supposed to be crispy and crunchy should have the same crunch and crispness every time it's eaten. (www.foodprocessing.com/articles/2016/sensory-properties-in-food-development)

Nutrients are important in any baked products. Here are some key nutritional facts about bread:

Calcium-White bread is fortified with calcium and four medium slices per day would provide over $30 \%$ of the recommended daily intake of calcium which we need every day to maintain healthy bones and teeth.

Fibre-Bread, especially wholemeal, is an important source of dietary fibre which helps to keep our digestive system healthy, helps control blood sugar and cholesterol levels and makes us feel fuller for longer.

Protein-Bread is a low fat source of protein which is required by our bodies for growth, renewal and repair.

Iron-White bread is fortified with iron. Iron is important for energy and concentration, a healthy immune system and healthy blood.

Vitamins \& Other Minerals-Bread contains a wide range of vitamins and minerals including B group vitamins thiamine (B1), Niacin (B3) which are important for releasing energy from food and maintaining healthy skin, eyes and nails. It contains the B vitamin Folate (Folic Acid) which is important for pregnancy as it can help to prevent neural tube defects such as spina bifida.

Energy-Bread is relatively low in calories. An average medium slice of white bread contains 77 calories, brown contains 72 calories and wholemeal contains 79 calories.

Fat-Bread is a low fat food. An average medium slice of white bread contains $0.6 \mathrm{~g}$ of fat, brown bread contains $0.7 \mathrm{~g}$ and wholemeal contains $0.9 \mathrm{~g}$. Just be careful with what you put on it and stick to healthy options for spreads and toppings.

Sugar-Most breads are low in sugar which is important for healthy teeth and maintaining a healthy weigh

(https://www.fob.uk.com > nutrition-and-health)

\section{Ingredients Used}


The ingredients used in this study are bread flour, yeast, milk, egg, salt, sugar and butter.

Table 1. The Ingredients used in Preparing Soft Roll Bread From Frozen Dough

\begin{tabular}{|c|c|c|}
\hline QUANTITY & UNIT & DESCRIPTION \\
\hline $21 / 2$ & Cup & Bread flour \\
\hline $1 / 2$ & Tablespoon & Yeast \\
\hline $3 / 4$ & cup & Fresh milk \\
\hline 2 & pieces & Egg \\
\hline 2 & Tablespoon & Sugar \\
\hline $1 / 4$ & teaspoon & Salt \\
\hline $1 / 8$ & part & butter \\
\hline
\end{tabular}

The table shows the quantity, unit of measurement and description of the ingredients to be used in preparing Soft Roll Bread from frozen dough.

\section{Procedure}

1. The flour was sifted and then it was set aside.

2. In a separate bowl, fresh milk, eggs, sugar and salt were mixed together and melted butter was added. ( Milk mixture)

3. The milk mixture and sifted flour were combined and kneaded until smooth to form the dough.

4. The dough was fermented for 25 minutes. ( first rising stage)

5. After the first rising stage it was punched to expel the air/gas incorporated during fermentation. Kneading was repeated.

6. The dough was frozen for one week and one month period. (second rising stage in the freezer)

7. After the experimented period of freezing, the dough was thawed and kneads again.

8. The dough was shaped accordingly.

9. Eggwash was brushed in the shaped the dough for shiny appearance when baked.

10. It was baked for $15-20$ minutes or until done.

Note: Eggwash is a mixture of eggyolk or egg whites and fresh milk to produce a shiny brownish top of the bread. 


\section{Results and Discussion}

The discussions below was the ratings obtained from the different respondents about the evaluation of soft roll bread from frozen dough ( one week old and one month old) that served as the basis in formulating the findings, conclusions and recommendations.

Table 1. Acceptability of Frozen Dough ( 1 week old) into Soft Roll Bread in terms of Appearance

\begin{tabular}{|c|c|c|c|c|c|c|c|c|c|}
\hline \multirow{2}{*}{$\begin{array}{l}\text { Indicative Statements } \\
\text { Soft Roll Dough In terms of } \\
\text { Appearance has........ }\end{array}$} & \multicolumn{3}{|c|}{ Teenagers } & \multicolumn{3}{|c|}{ Housewives } & \multicolumn{3}{|c|}{ Bakers } \\
\hline & & $\mathrm{CD}$ & 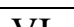 & 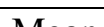 & $\mathrm{cD}$ & $\mathbf{Y I T}$ & & $\mathrm{CD}$ & $\mathbf{Y I T}$ \\
\hline $\begin{array}{l}\text { 1. a light golden brown } \\
\text { color }\end{array}$ & 4.80 & 0.41 & $\mathrm{HA}$ & 4.80 & 0.41 & HA & 4.96 & 0.20 & HA \\
\hline 2. a uniform round shape & 4.80 & 0.41 & $\mathrm{HA}$ & 4.68 & 0.56 & HA & 4.64 & 0.64 & HA \\
\hline $\begin{array}{l}\text { 3. a look free from foreign } \\
\text { materials }\end{array}$ & 4.92 & 0.28 & HA & 4.92 & 0.28 & HA & 4.80 & 0.50 & HA \\
\hline $\begin{array}{l}\text { 4. an outlook like } \\
\text { commercially available } \\
\text { bread }\end{array}$ & 4.64 & 0.70 & HA & 4.88 & 0.33 & HA & 4.92 & 0.28 & HA \\
\hline $\begin{array}{l}\text { 5. an indication of } \\
\text { freshness }\end{array}$ & 4.84 & 0.37 & HA & 4.72 & 0.46 & $\mathrm{HA}$ & 4.76 & 0.44 & $\mathrm{HA}$ \\
\hline Over-all & 4.80 & 0.22 & HA & 4.80 & 0.20 & HA & 4.82 & 0.20 & HA \\
\hline Grand Mean & & & & - & hly & eept & & & \\
\hline
\end{tabular}

Legend:

$\begin{array}{llll}\text { Scale } & \text { Range } & \text { Remarks } & \text { Verbal Interpretation } \\ 5 & 4.21-5.00 & \text { Strongly Agree (SA) } & \text { Highly Acceptable } \\ 4 & 3.41-4.20 & \text { Agree (A) } & \text { Acceptable } \\ 3 & 2.61-3.40 & \text { Moderately Agree (MA) } & \text { Moderately Acceptable } \\ 2 & 1.81-2.60 & \text { Disagree (D) } & \text { Slightly Acceptable } \\ 1 & 1.00-1.80 & \text { Strongly Disagree (SD) } & \text { Not Acceptable }\end{array}$

Table 2. Acceptability of Frozen Dough ( 1 week old) into Soft Roll Bread in terms of Aroma

\begin{tabular}{|c|c|c|c|c|c|c|c|c|c|}
\hline \multirow{3}{*}{$\begin{array}{l}\text { Indicative Statements } \\
\text { Soft Roll Dough In terms of } \\
\text { Aroma has........ }\end{array}$} & \multirow{2}{*}{\multicolumn{3}{|c|}{ Teenagers }} & \multirow{2}{*}{\multicolumn{3}{|c|}{ Housewives }} & \multirow{2}{*}{\multicolumn{3}{|c|}{ Bakers }} \\
\hline & & & & & & & & & \\
\hline & Mean & SD & VI & Mean & SD & VI & Mean & SD & VI \\
\hline 1.a distinct aroma of bread & 4.84 & 0.47 & $\mathrm{HA}$ & 4.92 & 0.28 & HA & 5.00 & 0.00 & HA \\
\hline 2. a pleasing odor & 4.84 & 0.47 & $\mathrm{HA}$ & 4.72 & 0.54 & $\mathrm{HA}$ & 4.76 & 0.60 & $\mathrm{HA}$ \\
\hline $\begin{array}{l}\text { 3. a smell free from } \\
\text { unpleasant odor }\end{array}$ & 4.88 & 0.33 & $\mathrm{HA}$ & 4.92 & 0.28 & HA & 4.68 & 0.48 & $\mathrm{HA}$ \\
\hline $\begin{array}{l}\text { 4. an invigorating freshly } \\
\text { baked aroma }\end{array}$ & 4.80 & 0.58 & HA & 4.80 & 0.41 & HA & 4.76 & 0.44 & $\mathrm{HA}$ \\
\hline $\begin{array}{l}\text { 5. an undetectable yeast } \\
\text { odor }\end{array}$ & 4.68 & 0.56 & HA & 4.76 & 0.52 & HA & 4.80 & 0.41 & $\mathrm{HA}$ \\
\hline Over-all & 4.81 & 0.23 & HA & 4.82 & 0.18 & $\mathrm{HA}$ & 4.80 & 0.20 & HA \\
\hline Grand Mean & & & & $\mathbf{H}$ & $1 \mathrm{~A}$ & able & & & \\
\hline
\end{tabular}


Table 3. Acceptability of Frozen Dough ( 1 week old) into Soft Roll Bread in terms of Taste

\begin{tabular}{|c|c|c|c|c|c|c|c|c|c|}
\hline \multirow{3}{*}{$\begin{array}{l}\text { Indicative Statements } \\
\text { Soft Roll Dough In terms of } \\
\text { Taste has........ }\end{array}$} & \multirow{2}{*}{\multicolumn{3}{|c|}{ Teenagers }} & \multirow{2}{*}{\multicolumn{3}{|c|}{ Housewives }} & \multirow{2}{*}{\multicolumn{3}{|c|}{ Bakers }} \\
\hline & & & & & & & & & \\
\hline & Mean & SD & VI & Mean & SD & VI & Mean & SD & VI \\
\hline 1. a mild yeast taste & 4.88 & 0.33 & HA & 4.92 & 0.28 & HA & 4.96 & 0.20 & HA \\
\hline 2. an agreeable bread taste & 4.72 & 0.46 & $\mathrm{HA}$ & 4.96 & 0.20 & HA & 4.76 & 0.44 & HA \\
\hline $\begin{array}{l}\text { 3. a rich and delicate bread } \\
\text { flavor }\end{array}$ & 4.88 & 0.44 & $\mathrm{HA}$ & 4.80 & 0.50 & HA & 4.92 & 0.28 & HA \\
\hline $\begin{array}{l}\text { 4. a taste similar to } \\
\text { commercially made } \\
\text { bread }\end{array}$ & 4.72 & 0.61 & HA & 4.84 & 0.37 & HA & 4.92 & 0.28 & $\mathrm{HA}$ \\
\hline $\begin{array}{l}\text { 5. an identified fresh taste } \\
\text { of ingredients }\end{array}$ & 4.88 & 0.44 & HA & 4.88 & 0.33 & HA & 4.92 & 0.28 & HA \\
\hline Over-All & 4.82 & 0.22 & HA & 4.88 & 0.18 & HA & 4.90 & 0.14 & HA \\
\hline Grand Mean & & & & $6-1$ & y & plë & & & \\
\hline
\end{tabular}

Table 4. Acceptability of Frozen Dough ( 1 week old) into Soft Roll Bread in terms of Texture

\begin{tabular}{|c|c|c|c|c|c|c|c|c|c|}
\hline Indicative Statements & & & & & & & & & \\
\hline Soft Roll Dough In terms of & & enage & & & usewi & & & Baker & \\
\hline Texture has......... & Mean & SD & VI & Mean & SD & VI & Mean & SD & VI \\
\hline $\begin{array}{l}\text { 1. a smooth mouth feel } \\
\text { when chewed }\end{array}$ & 5.00 & 0.00 & HA & 4.92 & 0.28 & HA & 5.00 & 0.00 & HA \\
\hline 2. a fine velvety texture & 4.72 & 0.54 & HA & 4.84 & 0.37 & HA & 4.88 & 0.33 & HA \\
\hline 3. a grain less texture & 4.96 & 0.20 & HA & 4.80 & 0.41 & HA & 5.00 & 0.00 & HA \\
\hline 4. a no compact texture & 4.88 & 0.33 & HA & 4.88 & 0.44 & HA & 4.92 & 0.28 & HA \\
\hline $\begin{array}{l}\text { 5. a tender inner part of } \\
\text { bread }\end{array}$ & 4.76 & 0.60 & HA & 4.88 & 0.33 & HA & 4.88 & 0.28 & HA \\
\hline Over-All & 4.86 & 0.14 & HA & 4.86 & $\mathbf{0 . 2 0}$ & $\mathbf{A}$ & 4.94 & $\mathbf{0 . 1 0}$ & HA \\
\hline
\end{tabular}

As depicted in the tables 1-4, the result of evaluation on soft roll bread from one (1) week frozen dough by the different group of respondents as to appearance, aroma, taste and texture got a grand mean score of 4.80 , 4.81. 4.86 and 4.86 respectively with a verbal interpretation of highly acceptable.

The bakers who are the most skillful and knowledgeable in baking soft roll bread gave the highest evaluation score on appearance, taste and texture with the mean score of 4.82, 4.90 and 4.94 respectively while the housewives gave the highest evaluation on aroma with the mean score of 4.82 . 
Table 5. Difference in the Acceptability of Frozen Dough (1 week old) into Soft Roll bread

\begin{tabular}{|l|l|l|l|l|l|l|}
\hline \multirow{2}{*}{ Criteria } & \multicolumn{3}{c|}{ Mean } & \multirow{2}{*}{ F } & \multirow{2}{*}{ p } & Remarks \\
\cline { 2 - 4 } \cline { 7 - 8 } & Teenagers & Housewives & Bakers & F & \\
\hline Appearance & 4.80 & 4.80 & 4.82 & 0.05 & 0.952 & NS \\
\hline Aroma & 4.81 & 4.82 & 4.80 & 0.09 & 0.915 & NS \\
\hline Taste & 4.82 & 4.88 & 4.90 & 1.30 & 0.279 & NS \\
\hline Texture & 4.86 & 4.86 & 4.94 & 1.93 & 0.153 & NS \\
\hline
\end{tabular}

Table 5 shows the result on the difference in the acceptability of soft roll bread from one (1) week frozen dough. It indicates that there is no significant difference on the level of acceptability of soft roll bread after the evaluation done by the teenagers, housewives and bakers who are the respondents of this experimental study.

\section{Appearance}

Table 6. Acceptability of Frozen Dough ( 1 month old) into Soft Roll Bread in terms of

\begin{tabular}{|c|c|c|c|c|c|c|c|c|c|}
\hline \multirow{2}{*}{$\begin{array}{l}\text { Indicative Statements } \\
\text { Soft Roll Dough In terms of } \\
\text { Appearance has........ }\end{array}$} & \multicolumn{3}{|c|}{ Teenagers } & \multicolumn{3}{|c|}{ Housewives } & \multicolumn{3}{|c|}{ Bakers } \\
\hline & Mean & SD & VI & Mean & SD & VI & Mean & SD & $\overline{\text { VI }}$ \\
\hline $\begin{array}{l}\text { 1. a light golden brown } \\
\text { color }\end{array}$ & 3.45 & 0.51 & $\mathrm{~A}$ & 3.85 & 0.37 & $\mathrm{~A}$ & 3.80 & 0.41 & $\mathrm{~A}$ \\
\hline 2. a uniform round shape & 3.50 & 0.51 & $\mathrm{~A}$ & 3.80 & 0.41 & $\mathrm{~A}$ & 3.85 & 0.37 & $\mathrm{~A}$ \\
\hline $\begin{array}{l}\text { 3. a look free from foreign } \\
\text { materials }\end{array}$ & 3.45 & 0.53 & A & 3.85 & 0.37 & A & 3.90 & 0.31 & A \\
\hline $\begin{array}{l}\text { 4. an outlook like } \\
\text { commercially available } \\
\text { bread }\end{array}$ & 3.70 & 0.47 & A & 4.00 & 0.00 & $\mathrm{~A}$ & 3.90 & 0.31 & $\mathrm{~A}$ \\
\hline $\begin{array}{l}\text { 5. an indication of } \\
\text { freshness }\end{array}$ & 3.85 & 0.37 & $\mathrm{~A}$ & 4.00 & 0.00 & $\mathrm{~A}$ & 3.80 & 0.41 & $\mathrm{~A}$ \\
\hline Over-all & 3.59 & 0.23 & $\mathrm{~A}$ & 3.90 & 0.14 & $\mathrm{~A}$ & 3.85 & \begin{tabular}{|l|}
0.21 \\
\end{tabular} & $\mathrm{~A}$ \\
\hline Grand Mean & & & & $3.78--$ & $\overline{\operatorname{ccept}}$ & & & & \\
\hline
\end{tabular}

Table 7. Acceptability of Frozen Dough ( 1 month) into Soft Roll Bread in terms of Aroma

\begin{tabular}{|c|c|c|c|c|c|c|c|c|c|}
\hline \multirow{3}{*}{$\begin{array}{l}\text { Indicative Statements } \\
\text { Soft Roll Dough In terms of } \\
\text { Aroma has........ }\end{array}$} & \multirow{2}{*}{\multicolumn{3}{|c|}{ Teenagers }} & \multirow{2}{*}{\multicolumn{3}{|c|}{ Housewives }} & \multirow{2}{*}{\multicolumn{3}{|c|}{ Bakers }} \\
\hline & & & & & & & & & \\
\hline & Mean & SD & VI & Mean & SD & VI & Mean & SD & VI \\
\hline 1. a distinct aroma of bread & 3.65 & 0.49 & A & 3.40 & 0.50 & A & 3.60 & 0.50 & A \\
\hline 2. a pleasing odor & 4.00 & 0.00 & A & 3.55 & 0.51 & A & 3.95 & 0.22 & A \\
\hline $\begin{array}{l}\text { 3. a smell free from } \\
\text { unpleasant odor }\end{array}$ & 3.65 & 0.49 & $\mathrm{~A}$ & 3.55 & 0.51 & $\mathrm{~A}$ & 3.95 & 0.22 & $\mathrm{~A}$ \\
\hline $\begin{array}{l}\text { 4. an invigorating } \\
\text { freshly baked aroma }\end{array}$ & 4.00 & 0.00 & A & 3.80 & 0.41 & A & 3.80 & 0.41 & A \\
\hline $\begin{array}{l}\text { 5. an undetectable } \\
\text { yeast odor }\end{array}$ & 3.85 & 0.41 & A & 3.60 & 0.50 & $\mathrm{~A}$ & 3.75 & 0.44 & $\mathrm{~A}$ \\
\hline Over-all & 3.82 & 0.17 & $\mathrm{~A}$ & 3.58 & 0.24 & $\mathrm{~A}$ & 3.81 & 0.20 & $\mathrm{~A}$ \\
\hline Grand Mean & & & 74. & cept: & & & & & \\
\hline
\end{tabular}


Table 8. Acceptability of Frozen Dough ( 1 month) into Soft Roll Bread in terms of Taste

\begin{tabular}{|c|c|c|c|c|c|c|c|c|c|}
\hline \multirow{3}{*}{$\begin{array}{l}\text { Indicative Statements } \\
\text { Soft Roll Dough In terms of } \\
\text { Taste has........ }\end{array}$} & \multirow{2}{*}{\multicolumn{3}{|c|}{ Teenagers }} & \multirow{2}{*}{\multicolumn{3}{|c|}{ Housewives }} & \multirow{2}{*}{\multicolumn{3}{|c|}{ Bakers }} \\
\hline & & & & & & & & & \\
\hline & Mean & SD & VI & Mean & SD & VI & Mean & SD & VI \\
\hline 1. a mild yeast taste & 3.00 & 0.52 & MA & 3.33 & 0.47 & MA & 3.20 & 0.54 & MA \\
\hline 2. an agreeable bread taste & 3.27 & 0.44 & MA & 3.27 & 0.85 & MA & 2.80 & 0.65 & MA \\
\hline $\begin{array}{l}\text { 3. a rich and delicate bread } \\
\text { flavor }\end{array}$ & 3.20 & 0.75 & MA & 2.93 & 0.85 & MA & 2.87 & 0.62 & MA \\
\hline $\begin{array}{l}\text { 4. a taste similar to } \\
\text { commercially made } \\
\text { bread }\end{array}$ & 3.33 & 0.79 & MA & 3.07 & 0.68 & MA & 3.07 & 0.68 & MA \\
\hline $\begin{array}{l}\text { 5. an identified fresh taste } \\
\text { of ingredients }\end{array}$ & 3.13 & 0.50 & MA & 3.07 & 0.77 & MA & 3.33 & 0.47 & MA \\
\hline Over-All & 3.19 & 0.63 & MA & 3.13 & 0.75 & MA & 3.05 & 0.63 & \\
\hline Grand Mean & \multicolumn{9}{|c|}{ 3.12 - Moderately Acceptable } \\
\hline
\end{tabular}

Table 9. Acceptability of Frozen Dough ( 1 month) into Soft Roll Bread in terms of Texture

\begin{tabular}{|c|c|c|c|c|c|c|c|c|c|}
\hline \multirow{3}{*}{$\begin{array}{l}\text { Indicative Statements } \\
\text { Soft Roll Dough In terms of } \\
\text { Texture has........ }\end{array}$} & \multirow{2}{*}{\multicolumn{3}{|c|}{ Teenagers }} & \multirow{2}{*}{\multicolumn{3}{|c|}{ Housewives }} & \multirow{2}{*}{\multicolumn{3}{|c|}{ Bakers }} \\
\hline & & & & & & & & & \\
\hline & Mean & SD & VI & Mean & SD & VI & Mean & SD & VI \\
\hline $\begin{array}{l}\text { 1. a smooth mouth feel } \\
\text { when chewed }\end{array}$ & 3.65 & 0.49 & $\mathrm{~A}$ & 3.85 & 0.37 & $\mathrm{~A}$ & 3.95 & 0.22 & $\mathrm{~A}$ \\
\hline 2. a fine velvety texture & 3.75 & 0.44 & $\mathrm{~A}$ & 3.70 & 0.47 & $\mathrm{~A}$ & 3.75 & 0.44 & $\mathrm{~A}$ \\
\hline 3. a grain less texture & 3.80 & 0.41 & $\mathrm{~A}$ & 3.70 & 0.47 & $\mathrm{~A}$ & 3.80 & 0.41 & $\mathrm{~A}$ \\
\hline 4. a no compact texture & 3.85 & 0.37 & $\mathrm{~A}$ & 4.00 & 0.00 & $\mathrm{~A}$ & 3.95 & 0.22 & $\mathrm{~A}$ \\
\hline $\begin{array}{l}\text { 5. a tender inner part of } \\
\text { bread }\end{array}$ & 3.70 & 0.47 & $\mathrm{~A}$ & 3.85 & 0.37 & $\mathrm{~A}$ & 3.95 & 0.22 & $\mathrm{~A}$ \\
\hline Over-All & 3.75 & 0.25 & $\mathbf{A}$ & 3.82 & 0.20 & $\mathbf{A}$ & 3.88 & 0.18 & $\mathbf{A}$ \\
\hline
\end{tabular}

As reflected in table 6-9, the result of the evaluation of soft roll bread from one (1) month frozen dough by the different group of respondents as to appearance, aroma, and texture got a grand mean score of $3.78,3.74$, and 3.82 respectively with a verbal interpretation of acceptable while taste got a grand mean of 3.12 which was verbally interpreted as moderately acceptable.

The teenagers gave the highest evaluation score on aroma and taste with the mean score of 3.82 and 3.19 respectively while the housewives gave the highest evaluation score on appearance with the mean score of 3.90 and the bakers gave also the highest evaluation score on texture with the grand mean of 3.88 
Table 10. Difference in the Acceptability of Frozen Dough (1 month) into Soft Rolbread

\begin{tabular}{|c|c|c|c|c|c|c|}
\hline \multirow[b]{2}{*}{ Criteria } & \multicolumn{3}{|c|}{ Mean } & \multirow[b]{2}{*}{$\mathbf{F}$} & \multirow[b]{2}{*}{ p } & \multirow{2}{*}{ Remarks } \\
\hline & Teenagers & Housewives & Bakers & & & \\
\hline Appearance & 3.59 & 3.90 & 3.85 & 14.17 & $<.001$ & $\mathrm{~S}$ \\
\hline Aroma & 3.82 & 3.58 & 3.81 & 8.68 & .001 & $\mathrm{~S}$ \\
\hline Taste & 3.19 & 3.13 & 3.05 & 0.29 & .753 & NS \\
\hline Texture & 3.75 & 3.82 & 3.88 & 1.87 & .163 & NS \\
\hline
\end{tabular}

Table 10 shows the result on the difference in the acceptability of soft roll bread from one (1) month frozen dough. It indicates that there is no significant difference on the level of acceptability of soft roll bread after the evaluation done by the teenagers, housewives and bakers in terms of texture and taste while there is significant difference on the level of acceptability in terms of appearance and aroma.

\section{CONCLUSIONS}

The following conclusions were drawn from the discussions of this study:

1. The methods in making soft roll bread from frozen dough were considered acceptable since it does not require a state of the art equipment.

2. The palatability of soft roll bread from one week old frozen dough was highly acceptable as to its sensory qualities while the one month old frozen dough was only acceptable except on taste which was moderately acceptable only as rated by the different groups of respondents.

3. There is no significant difference on the palatability of soft bread from one week old frozen dough as to the sensory qualities while there is significant difference on the palatability of soft roll bread from one month old dough as to appearance and aroma as rated by the different group of respondents.

\section{RECOMMENDATIONS}

The following were the recommendations/suggestions on this study:

1. The soft roll bread from one week old frozen dough is recommended for laboratory testing to know if the nutrients are the same with the regular bread.

2. Further study should be conducted to test the shelf life of the soft roll bread from one week old frozen dough. 
3. A study on marketability of this study must be conducted.

4. Develop other recipe like empanada, bread roll and savory tarts based from this study.

\section{References}

Cauvain, Stanley (2015). Technology of Breadmaking. Springer. p. 377. ISBN 978-3-319-14687-4.

De Leon and De Guzman (2006). Preservation of Philippine Foods. Phoenix Publishing House, Quezon City.

Edwards, W.P. (2007). The science of bakery products. Cambridge, Eng: Royal Society of Chemistry. p. 68. ISBN 0-85404-486-8.

Gislen, Wayne. Professional Baking. 2d ed. New York: John Wiley, 2004.

Peña, R. J. "Wheat for bread and other foods". Food and Agriculture Organization. Retrieved 1 October 2016.

www.foodprocessing.com/articles/2016/sensory-properties-in-food-development)

www.wisegeekhealth.com/what-is-palatability.htm

www.foodafactoflife.org.uk/Sheet.aspx?siteId=19\&sectionId83\&contentId=308https://www.fob.uk.com > nutrition-and-health

http://www.empirebake.com/commercial_bakery_equipment.asp 